\title{
Dry matter losses of grass, lucerne and maize silages in bunker silos
}

\author{
Brigitte Köhler ${ }^{1}$, Michael Diepolder ${ }^{2}$, Johannes Ostertag ${ }^{1}$, Stefan Thurner ${ }^{3}$ and Hubert Spiekers ${ }^{1}$, \\ Bavarian State Research Center for Agriculture, Vöttinger Str. 38, D-85354 Freising, Germany \\ ${ }^{1}$ Institute for Animal Nutrition and Feed Management \\ ${ }^{2}$ Institute for Agricultural Ecology, Organic Farming and Soil Protection \\ ${ }^{3}$ Institute for Agricultural Engineering and Animal Husbandry \\ e-mail: brigitte.koehler@Ifl.bayern.de
}

\begin{abstract}
An efficient feed management is important for a sustainable and economic agricultural production. One of the main points for improving the efficiency is the reduction of feed losses. In the present investigation the dry matter (DM) losses of grass, lucerne and maize silages in farm scaled bunker silos were analysed. The method of determining DM losses was the total-in versus total-out DM mass flow of the silos, including the determination of DM content and other silage parameters via manual sampling. The results taken from 48 silos showed on average for all investigated crops $9-12 \%$ of DM losses. Density and feed out rate showed a negative correlation to DM losses in maize silages. According to the applied method for determining DM losses on farm scale, a guideline of $8 \%$ can be suggested for maximum DM losses in bunker silos for grass and maize silages. The described method seems to be applicable for improving the feed management by using largely automated measurements on the harvest and feeding side.
\end{abstract}

Key words: farm scale, feed management, fodder mixer wagon, silage management, total-in vs. total-out

\section{Introduction}

Agricultural production faces worldwide challenges due to climate change, population growth and loss of agricultural land. Therefore, the efficiency optimisation in feed management is highly relevant for a sustainable and economic feed production (Humphreys et al. 2009). One major possibility to improve the efficiency is the reduction of feed losses in the silos. An efficient silage system for feed production should ensure a low level of losses and a high silage quality. In respect of the losses at storage, investigations indicated DM losses on average, established during ensiling and storage, of approximately $16 \%$ (Watson and Nash 1960) and 32\% (Bastiman and Altman 1985), respectively. However, only $7 \%$ of energy losses during the ensiling process are supposed to be unavoidable (Zimmer 1980). Because those results were obtained from measurements in bench scale silos, transferability of these test results to practice is questionable. Mayne and Gordon (1986) reported 6\% DM losses of wilted grass silages in silos of $100 \mathrm{t}$ capacity. However, aerobic deterioration and reheating as discussed by Spiekers et al. (2009) as a major source of DM losses has not been taken into account. Therefore, concerning DM losses of farm scale bunker silos, reliable values are still not available. For this reason, in the present study DM losses at storage for $48 \mathrm{si}-$ los were examined. The silos were investigated by the total-in versus total-out procedure to obtain reliable information about acceptable dimensions of DM losses for farm scale bunker silos. The aim of the study was to define promising starting points in order to improve the efficiency in feed management and furthermore, to develop a useful tool to control DM losses in farm scale bunker silos.

\section{Material and methods}

The mass flow of silages was examined on one organic and two conventional farms. These farms belong to the Bavarian State Research Center for Agriculture with a total livestock of between 70 to 190 dairy cows. The longterm mean precipitation ranges from $800-1100 \mathrm{~mm}$ and the annual mean temperature from $7-8{ }^{\circ} \mathrm{C}$, respectively. Data were collected over a period of four years from 2008 to 2011. The DM losses were determined from 26 grass, 4 lucerne and 18 maize silos. The feed sources of the farms involved included permanent grassland, maize (all farms) and further forage crops such as grass-clover mixture, lucerne or annual ryegrass on two farms. Permanent grassland was dominated by grass species (approximately $80 \%$ contribution to total DM), in particular by Alopecurus pratensis. Only the organic farm had a proportion of $40-50 \%$ of grass-red clover-mixture, which is 
analysed with the grass silos. The fertilisation level ranged from 100-290 kg N ha-1 for grassland and from 150$200 \mathrm{~kg} \mathrm{~N} \mathrm{ha}^{-1}$ for maize. On all farms five cuttings per year from permanent grassland are the usual practice. In most cases, the wilting period did not exceed 24 hours for grass and 48 hours for lucerne. Annual yields were on average 6-10 t DM ha ${ }^{-1}$ for grass, 8 t DM ha-1 for lucerne and 10-17 t DM ha ${ }^{-1}$ for maize, respectively. The good practice of ensiling on the farms was in accordance with the guidelines recommended by the German research and advisory group feed preservation (DLG 2011). At harvest time the ensiled materials were sampled and analysed for their characteristics (Table 1).

All crops were harvested with a self-propelled forage harvester, cut to a theoretical chopping length of 20-50 $\mathrm{mm}$ for grass, grass-clover and lucerne or 4-9 $\mathrm{mm}$ for maize. Silage additives were used for lucerne, partly for grass, but not for maize. For lucerne, a chemical additive was applied consisting of a mixture of sodium nitrate and hexamethylenetetramine $\left(2 \mathrm{It} \mathrm{t}^{-1} \mathrm{FM}\right)$. On the organic farm, molasses $\left(30 \mathrm{It}^{-1}\right)$ and homofermentative lactic acid bacteria (L. plantarum, $3 * 10^{5} \mathrm{cfu} \mathrm{t}^{-1}$ ) were added to grass and grass-clover mixture. On one conventional farm, a mixture of L. plantarum, L. rhamnosus, P. pentosaceus, L. buchneri and L. brevis was used for grass. On the second conventional farm no silage additives were applied. The grass and maize silages were conserved in side walled bunker silos using silo pit foils, underlay films, silage films and protective covers and weighed down with gravel bags. The bunker silos capacities ranged from $170 \mathrm{~m}^{3}$ to $690 \mathrm{~m}^{3}$. The harvested mass per hour did not exceed the fourfold weight of vehicles used for compaction. All silos were kept closed for at least six weeks.

The total-in versus total-out procedure is defined as the method of determination for the DM losses in the farm scale bunker silos. Figure 1 shows the principle behind the measurements from harvesting to feeding. During the harvest, every wagonload was weighed on a $40 \mathrm{t}$ cart scale (measurement accuracy $\pm 10 \mathrm{~kg}$ ). In general, four samples per ha were retrieved from the harvested ensiling materials. The samples were taken from each wagonload after unloading with a random sampling of 5-10 single samples. Pooled samples were used for analysing DM contents and crude nutrients. Results of the crude nutrient content determinations were transferred to the respective silos. The analysis of sugars was performed by NIRS. The buffering capacity reveals the quantity of lactic acid in $\mathrm{g}$, which had to be added to lower the $\mathrm{pH}$ of $1 \mathrm{~kg}$ DM to 4.0 .

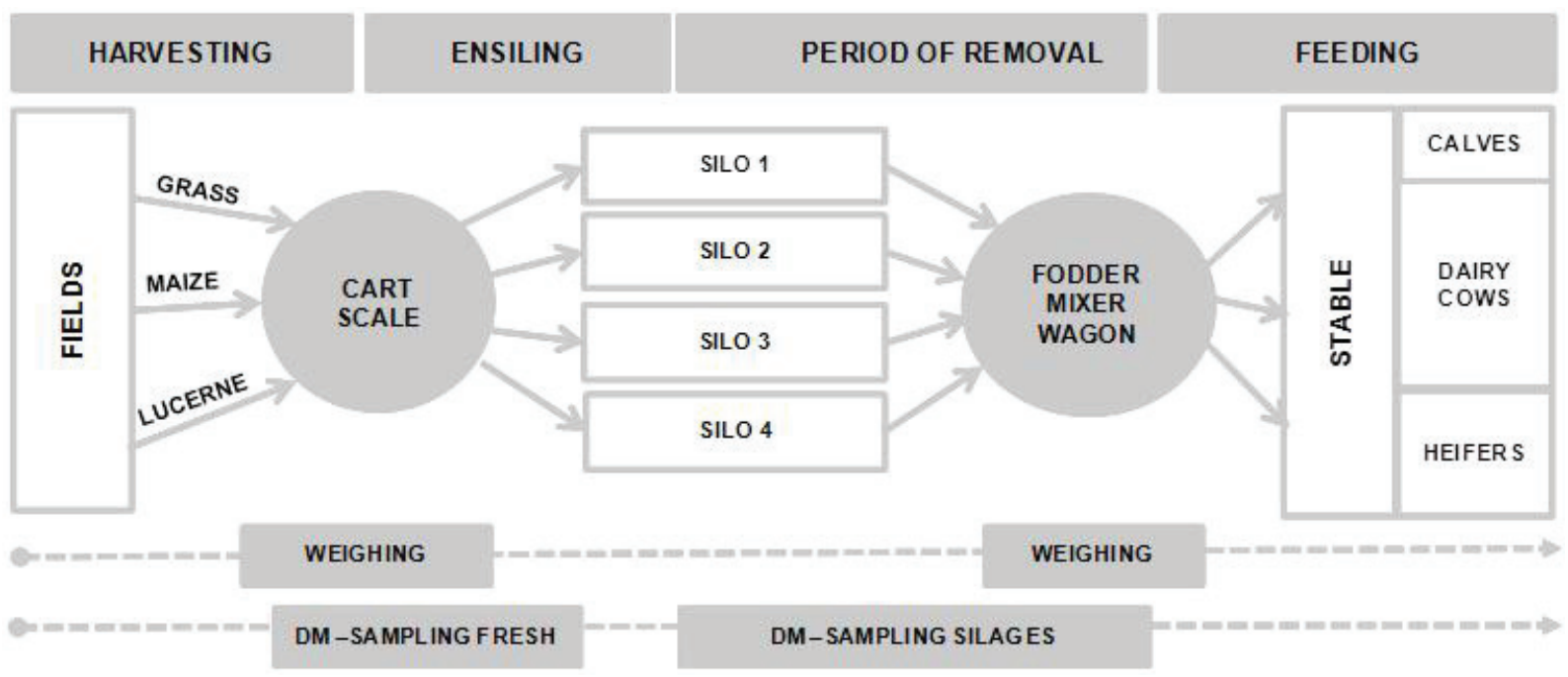

Fig. 1. Principle of measurements used for the total-in vs. total-out method

During the period of removal (three months on average), all feedstuffs were taken out of the silos by a fodder mixer wagon equipped with a digital weighing system. Therefore each feed portion was weighed separately. The DM content of the silages was determined weekly, using a core drill for sampling (Pioneer ${ }^{\mathrm{TM}}$-drilling jig; drilling depth $40 \mathrm{~cm}$ ). Three samples were taken at different heights from the face of the silos. The DM samples were dried in a cabinet dryer and subsequently, corrected for volatiles (Weißbach and Kuhla 1995). The applied equations for grass/lucerne were $\mathrm{DM}_{\text {corrected }}(\%)=2.08+0.975 * \mathrm{DM}_{\text {uncorrected }}(\%)$ and for maize $\mathrm{DM}_{\text {corrected }}(\%)=2.22+0.96 * \mathrm{DM}_{\text {un- }}$ (\%). Silo controllings (as described by Spiekers et al. 2009) were undertaken once, when half of the silo had been removed. As parameters of the silages the fermentation quality, DM density and temperature were analysed (Table 2). The mean density in the silos was calculated using three measurements (top, middle, bottom) at 
the silo face, using a special core drill $(r=4.60 \mathrm{~cm}$; drilling depth approximately $20 \mathrm{~cm})$. Temperatures were measured at six points at a depth of $40 \mathrm{~cm}$. The feed out rate from each silo was calculated from the feed removal on a weekly basis.

The determination of DM losses was calculated by subtracting the removed DM masses from the ensiled masses, summing up all single values. Spoiled materials, which were not used for feeding, were regarded as losses. Evaluation of all data was carried out by statistical analysis (SAS 9.2). The normal distribution was tested, correlations were calculated with the Pearson correlation coefficient and for boxplots a SAS macro program (Friendly 2005) was used. The correlations between silage density and feed out rate to DM losses were analysed.

\section{Results and discussion}

With reference to the nutrient values and fermentation coefficients, we observed a wide range of the investigated ensiled materials (Table 1). However, on average a good ensilability was achieved according to Weißbach et al. (1974). Nevertheless, the wide range of the material gives a better transferability of the results to practical conditions. In accordance with the predicted ensilability, good fermentation qualities could be obtained (Table 2). Major differences were found for grass silages. In 7 of 19 grass silages butyric acid was analysed and is a sign for an unfavourable ensiling process.

Table 1. Chemical composition, feeding value and fermentation coefficients of three different types of ensiled material

\begin{tabular}{|c|c|c|c|c|c|c|c|}
\hline & \multirow[b]{2}{*}{ unit } & \multicolumn{2}{|c|}{ Grass $(n=26)$} & \multicolumn{2}{|c|}{ Maize $(n=18)$} & \multicolumn{2}{|c|}{ Lucerne $(n=4)$} \\
\hline & & mean & $\min -\max$ & mean & $\min -\max$ & mean & $\min -\max$ \\
\hline DM & $\mathrm{g} \mathrm{kg}^{-1} \mathrm{DM}$ & 316 & $229-503$ & 356 & 295-451 & 316 & $222-385$ \\
\hline $\mathrm{CP}^{1}$ & $\mathrm{~g} \mathrm{~kg}^{-1} \mathrm{DM}$ & 176 & $137-237$ & 72 & $61-79$ & 199 & $152-225$ \\
\hline ADFom $^{2}$ & $\mathrm{~g} \mathrm{~kg}^{-1} \mathrm{DM}$ & 300 & $213-338$ & 250 & 189-294 & 369 & $356-382$ \\
\hline NEL & $\mathrm{MJ} \mathrm{kg}^{-1} \mathrm{DM}$ & 5.9 & $5.5-6.7$ & 6.5 & $6.2-7.0$ & 5.7 & $5.5-5.9$ \\
\hline $\mathrm{FC}^{3}$ & - & 42 & $33-55$ & 54 & $44-69$ & 36 & $26-45$ \\
\hline
\end{tabular}

${ }^{1} \mathrm{CP}$ : crude protein, ${ }^{2} \mathrm{ADFom}$ : acid detergent fibre, without residual crude ash; ${ }^{3} \mathrm{FC}$ : fermentation coefficient $=\mathrm{DM} \%+8 *$ (sugar $/$ buffering capacity) according to Weißbach et al. 1974.

Table 2. Parameters for preservation quality and feed management for the three different types of silage material

\begin{tabular}{|c|c|c|c|c|c|c|c|c|c|c|}
\hline \multirow[b]{2}{*}{ Parameter } & \multirow[b]{2}{*}{ unit } & \multicolumn{3}{|c|}{ Grass } & \multicolumn{3}{|c|}{ Maize } & \multicolumn{3}{|c|}{ Lucerne } \\
\hline & & $\mathrm{n}$ & mean & $\min -\max$ & $\mathrm{n}$ & mean & $\min -\max$ & $\mathrm{n}$ & mean & $\min -\max$ \\
\hline Dry matter (DM) & $\mathrm{g} \mathrm{kg}^{-1}$ & 22 & 293 & $223-419$ & 16 & 356 & $286-441$ & 4 & 352 & $268-409$ \\
\hline Lactic acid & $\mathrm{g} \mathrm{kg}^{-1} \mathrm{DM}$ & 19 & 55 & $23-129$ & 14 & 48 & $26-69$ & 4 & 72 & $46-94$ \\
\hline Acetic acid & $\mathrm{g} \mathrm{kg}^{-1} \mathrm{DM}$ & 19 & 22 & $7-50$ & 14 & 17 & $7-38$ & 4 & 30 & $18-50$ \\
\hline Propionic acid ${ }^{1}$ & $\mathrm{~g} \mathrm{~kg}^{-1} \mathrm{DM}$ & 5 & 3 & $2-5$ & 0 & - & - & 2 & 4 & $2-5$ \\
\hline Butyric acid ${ }^{1}$ & $\mathrm{~g} \mathrm{~kg}^{-1} \mathrm{DM}$ & 7 & 10 & $3-23$ & 0 & - & - & 2 & 8 & $2-14$ \\
\hline $\mathrm{pH}$ & -- & 19 & 4.4 & $3.8-4.8$ & 14 & 3.9 & $3.7-4.3$ & 4 & 4.7 & $4.4-5.3$ \\
\hline Density & $\mathrm{kg} \mathrm{m}^{-3} \mathrm{DM}$ & 22 & 194 & $155-278$ & 16 & 246 & $215-299$ & 4 & 244 & $203-288$ \\
\hline Feed out rate & m week ${ }^{-1}$ & 19 & 2.1 & $1.1-3.4$ & 18 & 2.1 & $1.0-3.6$ & 4 & 1.9 & $1.3-2.4$ \\
\hline Temperature & ${ }^{\circ} \mathrm{C}$ & 22 & - & $3-37$ & 16 & - & $2-23$ & 4 & - & $5-23$ \\
\hline
\end{tabular}

${ }^{1}$ Propionic and butyric acid: $\mathrm{n}=$ number of analysis which exceeded the limit of detection 
By the measurement of the temperature, a reheating was determined in 2 maize and 5 grass silages in the upper layers of the evaluated silos. The wide range of the compaction quality of the silages was in agreement with findings of Richter et al. (2009). In some cases compaction was lower than recommended for maize silages, primarily (DLG 2011). Altogether a high feed out rate on average could be realised due to the convenient proportion between silo face and feed removal per day. The general requirements for ensiling material, silage making and feed management were achieved at all farms. Hence transferability of the results to practice is justifiable.

The DM losses determined for 48 farm scale silos are presented in Figure 2. The collected data followed a normal distribution. For maize silages an average of 10\% DM losses was observed, for grass silages $9 \%$ and for lucerne silages $12 \%$, respectively. The average DM losses from these silage types seem to be low. This was unexpected, in particular of the grass silages, because DM losses of grass silages in laboratory scale exceeded those of maize silages (Thaysen et al. 2007). Grass silages, which were shown to be most heterogeneous, revealed the largest range of DM losses from $-2 \%$ to $26 \%$, followed by maize silages from $-4 \%$ to $19 \%$ and lucerne silages from $6 \%$ to $15 \%$.

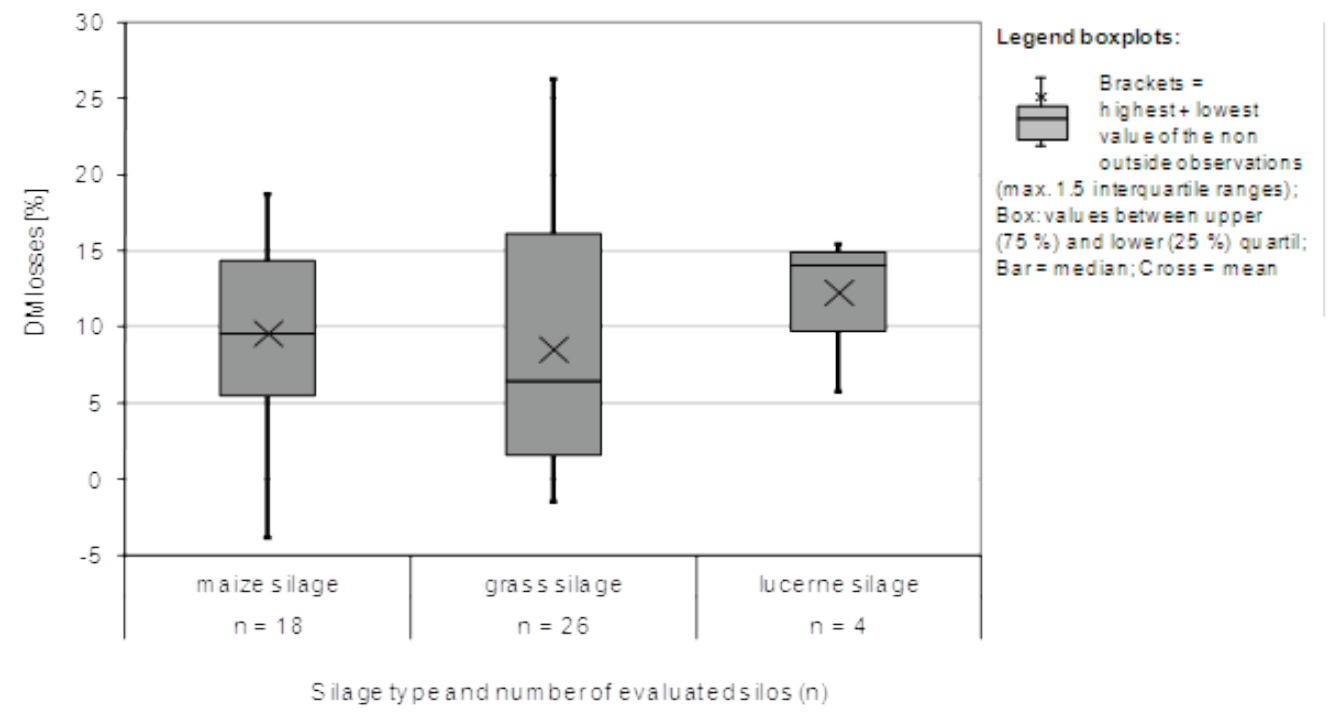

Fig. 2. DM losses (\%) of silages determined by the total-in vs. total-out method

With respect to other characteristics of silage quality the grass silages showed the highest variability for DM contents and densities. Nevertheless, for one grass silo $26 \%$ losses of DM were determined. For this silo an intense reheating could be observed, however, the appearance of butyric acid was found. The high DM losses could be explained with the occurrence of this parameters and the ascertained low feed out rate.

Further tests showed, that the feed out rate had a negative significant correlation coefficient with the DM losses for both silages (maize -0.555 , grass -0.570 ) (Table 3). A negative correlation with the density was significant for the maize silos (-0.625). Furthermore, no correlation between the density and the DM losses of grass silos was found.

Table 3. Correlation coefficients of density and feed out rate with the dry matter losses of the maize and grass silos

$$
\text { DM losses of maize silos }(n=18)
$$

DM losses of grass silos $(n=26)$

\begin{tabular}{llccc} 
Variable & $\mathrm{n}$ & correlation & $\mathrm{n}$ & correlation \\
\hline Density, kg m ${ }^{-3} \mathrm{DM}$ & 15 & $-0.625^{*}$ & 18 & -0.039 \\
Feed out rate, $\mathrm{m} \mathrm{week}^{-1}$ & 22 & $-0.555^{*}$ & 19 & $-0.570^{*}$ \\
\hline
\end{tabular}

*significance with: $0.05>p>0.01$ 
These relations should be taken into account, because in most cases maize silages did not reach the recommended density levels. However, besides density there are several other parameters causing DM losses in silos. Referring to the farm scale study of Borreani and Tabacco (2012), who investigated maize silages for aerobic deterioration, the influence of the recommended feed out rate was proven. Moreover, the mean feed out rate in the cited study was lower than in the present investigation. Our findings also exhibited low levels of DM losses in general. Compared to the values of other studies (McGechan 1989), it is probably attributed to the good ensiling practice and the partial high feed out rate on the participating farms.

As negative values for DM losses are impossible, they have to be ascribed to the precision of the method, which strongly depends on the accuracy of the data collection and their susceptibility to errors. Potential sources of error are an inadequate distribution of control points for DM determination, as well as inaccurate weighing by the fodder mixer wagon. The correctness and frequency of DM determination is crucial, especially for the investigation of the heterogeneous grass silages (Thurner et al. 2011). Therefore, progress of DM determination by the implementation of online NIRS systems on the fodder mixer wagon (Twickler et al. 2012) could be an improvement for the proposed method. Supported by technical measurements of the permanent process the method appears to be applicable for farms in spite of different procedures for feeding. In the present study, fifty percent of the ascertained values were below $8 \%$ of DM losses. Thus, according to the present results a maximum value of $8 \%$ unavoidable DM losses can be set as a guideline for bunker silos, independent of the crop. This method of control could be implemented by using technical measurements with justifiable effort on practical farms.

\section{Conclusions}

A method for the determination of DM losses in bunker silos has been described. The DM losses in grass silages seem to be comparable with those for maize, assuming there is a good practice of ensiling. The density and feed out rate showed a negative correlation to DM losses in maize silages. As a guideline for maximum DM losses in bunker silos, $8 \%$ emerged to be an adequate value. In spite of problems concerning data collection, the method seems to be adaptive and useful for commercial farms as a tool of control.

\section{Acknowledgements}

This study was financed by the Bavarian State Ministry of Food, Agriculture and Forestry", as part of the project "Efficient Feed Management and Nutrient Flows on Dairy Farms" (A/08/01).

\section{References}

Bastiman, B. \& Altman, J.F.B. 1985. Losses at various stages in silage making. Research and Development in Agriculture 2: 19-25.

Borreani, G. \& Tabacco, E. 2012. Effect of silo management factors on aerobic stability and extent of spoilage in farm maize silages. In: Kuoppala, K. et al. (eds.). Proceedings of the 16th International Silage Conference, 2-4 July, Hämeenlinna, Finland. p. 71-72.

DLG 2011: Praxishandbuch Futter- und Substratkonservierung. Frankfurt/Main: DLG-Verlag. 416 p. (in German).

Friendly, M. 2005. SAS Macro Programs for Statistical Graphics: boxplots: http://www.datavis.ca/sasmac/boxplot.html.

Humphreys, J., Aarts, H.F.M., Watson, C.J., Wachendorf, M., Le Gall, A., Taube, F. \& Pflimlin, A. 2009. Sustainable options for grassland-based dairy production in the northwest of Europe. Tearmann: Irish Journal of Agri-Environmental Research 7: 175-194.

Mayne, C.S. \& Gordon, F.J. 1986. Effect of harvesting system on nutrient losses during silage making. 2. In-silo losses. Grass and Forage Science 41: 341-351.

McGechan, M.B. 1989. A review of losses during conservation of grass forage. Part 2, storage losses. Journal of Agricultural Engineering Research 45: 1-30.

Richter, W., Zimmermann, N., Abriel, M., Schuster, M., Kölln-Höllrigl, K., Ostertag, J., Meyer, K., Bauer, J. \& Spiekers, H. 2009. Hygiene bayerischer Silagen: Validierung einer Checkliste zum Controlling am Silo. Bayerische Landesanstalt für Landwirtschaft. Schriftenreihe 9. 130 p. (in German).

Spiekers, H., Ostertag, J., Meyer, K., Bauer, J. \& Richter, W.I.F. 2009. Managing and controlling silos to avoid losses by reheating of grass silage. In: Broderick, G.A. et al. (eds.). Proceedings of the 15th International Silage Conference 27-29 July, Madison, USA. p. 317-318.

Thaysen, J., Honig, H., Kalzendorf, C., Spiekers, H. \& Staudacher, W. 2007. Silage Additives: Aspects of feed legislation, efficacy of DLG-approved products and recommendations for application. Übersichten Tierernährung 35: 55-91.

Thurner, S., Fröhner, A., Köhler, B. \& Demmel, M. 2011: Online measurement of yield and dry matter content of wilted grass with two forage harvesters - comparison with and verification of reference measurements. In: Stafford, J.V. (ed.). Precision Agriculture 2011. Proceedings of the 8th European Conference on Precision Agriculture 2011, 11-14 July, Prague, Czech Republic. p. 628-637. 
Twickler, P., Büscher, W. \& Maack, C. 2012. Sensor controlled total-mixed-ration for nutrient optimized feeding of dairy cattle. In: Kuoppala K. et al. (eds.). Proceedings of the 16th International Silage Conference, 2-4 July, Hämeenlinna, Finland. p. 316-317.

Watson, S.J. \& Nash, M.J. 1960. The conservation of grass and forage crops. Edinburgh: Oliver and Boyd. 758 p.

Weißbach, F. Schmidt, L., \& Hein, E. 1974. Method of anticipation of the run fermentation in silage making, based on the chemical composition of the green fodder. Proceedings of the 12th International Grassland Congress Section 2, Moscow, USSR. p. 663673. Cited in: DLG 2011.

Weißbach, F. \& Kuhla, S. 1995. Stoffverluste bei der Bestimmung des Trockenmassegehaltes von Silagen und Grünfutter: Entstehende Fehler und Möglichkeiten der Korrektur. Übersichten Tierernährung 23: 189-214. (in German).

Zimmer, E. 1980. Efficient silage systems. Proceedings of the British Grassland Society Occasional Symposium No 11 Brighton, UK. p. 186-197. 